\title{
Testicular Cancer cN3 TNM Finding v7
}

National Cancer Institute

\section{Source}

National Cancer Institute. Testicular Cancer CN3 TNM Finding v7. NCI Thesaurus. Code C89263.

Metastasis with a lymph node mass more than $5 \mathrm{~cm}$ in greatest dimension. (from AJCC 7th Ed.) 